Miami Nature Biotechnology Short Reports

TheScientificWorld (2001) 1 (S3), 91SR

ISSN 1532-2246; DOI 10.1100/tsw.2001.204

\title{
THE SUPER ANTI-APOPTOTIC FACTOR BCL-XFNK: A NOVEL MUTANT OF RAT BCL-XL WITH A GAIN-OF-FUNCTION PHENOTYPE
}

\author{
Sadamitsu Asoh*, Takashi Ohtsu, and Shigeo Ohta
}

Department of Biochemistry and Cell Biology, Institute of Gerontology, Nippon Medical School, 1-396, Kosugi-cho, Nakahara-ku, Kawasaki-city, Kanagawa-ken 211-8533, Japan

*sada@nms.ac.jp

INTRODUCTION. A powerful synthetic anti-apoptotic factor would be useful for future therapeutic applications in medicine. Analysis of the crystal structure of renatured human Bcl$\mathrm{x}_{\mathrm{L}}$ has suggested that it forms an ion channel (1). Additionally, Bcl- $\mathrm{x}_{\mathrm{L}}$ has been shown to form an ion channel in synthetic lipid membranes (2). We have independently determined the $\mathrm{x}$-ray structure of native rat $\mathrm{Bcl}-\mathrm{x}_{\mathrm{L}}$ with a $2.5 \AA$ resolution and found it to have nine intramolecular polar interactions to stabilize the central putative pore-forming domain ( $\alpha 5-\alpha 6$ helices) (3). We hypothesized that these hydrogen bonds may disturb the anti-apoptotic effect by inhibiting the insertion of the pore-forming domain into membranes. In the present study we designed a mutant $\mathrm{Bcl}-\mathrm{X}_{\mathrm{L}}$, named $\mathrm{Bcl}-\mathrm{xFNK}$ to make the $\alpha 5-\alpha 6$ helices more mobile or flexible by disturbing the formation of three hydrogen bonds which stabilize the tip of the putative poreforming domain.

METHODS. To construct Bcl-xFNK, three amino acid substitutions ( $\mathrm{Tyr}^{22}$ to Phe $[\mathrm{F}], \mathrm{Gln}^{26}$ to Asn [N] and $\mathrm{Arg}^{165}$ to Lys [K]) were introduced into rat $\mathrm{Bcl}-\mathrm{X}_{\mathrm{L}}$ by a two-step PCR mutagenesis. Chinese hamster $\mathrm{CHO} \mathrm{K} 1$ cells were cultured in D-MEM/F-12 medium containing $10 \%$ fetal bovine serum. Human Jurkat cells and IL-3 dependent murine cells, FDC-P1 and BaF/3, were cultured in RPMI 1640 medium containing 10 \% FBS. For FDC-P1 and $\mathrm{BaF} / 3$ cells, IL-3 was added in the medium. Plasmids were introduced into Jurkat, FDC-P1 and $\mathrm{BaF} / 3$ cells by electroporation and into $\mathrm{CHO}$ cells using Superfect. Stable transfectants Jurkat cells were treated with various death-inducing stimuli. CHO cell transfectants were deprived of serum. FDC-P1 and BaF/3 transfectant cells were incubated in the absence of IL-3. Surviving cells were counted by the trypan blue exclusion or by the WST- 1 assay. BIOTRAK p42/p44 MAP kinase enzyme assay system was used to measure the p42/p44 MAP kinase activity of cells.

RESULTS. When over expressed in Jurkat or CHO cells, Bcl-xFNK was markedly more potent than wild-type $\mathrm{Bcl}-\mathrm{x}_{\mathrm{L}}$ in prolonging survival against anti-Fas $(\mathrm{CH}-11)$, staurosporine, TN-16, camptothecin, hydroxyurea, trichostatin A, hydrogen peroxide, paraquat, a calcium ionophore (A23187), heat treatment and serum deprivation. Interestingly, Bcl-xFNK allowed IL-3-dependent FDC-P1 but not BaF/3 cells to grow without IL-3. In Bcl-xFNK transfectants of FDC-P1 and Jurkat cells, the p42/p44 MAP kinase was activated by 2 to 5 times, but not in $\mathrm{BaF} / 3$ and $\mathrm{CHO}$ cells. Thus, Bcl-xFNK might acquire a new function to activate the MAP kinase in a cell-type specific manner. 
DISCUSSION. These findings of this study suggest that the central $\alpha 5-\alpha 6$ pore-forming region of the anti-apoptotic factor Bcl- $\mathrm{x}_{\mathrm{L}}$ has a pivotal role in suppressing apoptosis. Bcl-xFNK would be useful for making commercially important anima cell lines robust to culture insults may more effectively prevent cell death in diseases such as ischemia than Bcl- $\mathrm{x}_{\mathrm{L}}$ and Bcl-2.

\section{REFERENCES.}

1. Muchmore, S.W., Sattler, M., Liang, H., Meadows, R.P., Harlan, J.E., Yoon, H.S., Nettesheim, D., Chang, B.S., Thompson, C.B., Wong, S.L., Ng, S.L., and Fesik, S.W. (1996) Nature 381, 335-341

2. Minn, A.J., Velez, P., Schendel, S.L., Liang, H., Muchmore, S.W., Fesik, S.W., Fill, M., and Thompson, C.B. (1997) Nature 385, 353-357

3. $\quad$ Aritomi, M., Kunishima, N., Inohara, N., Ishibashi, Y., Ohta, S., and Morikawa, K. (1997) J. Biol. Chem. 272, 27886-27892 